\title{
Mengapa remaja agresi?
}

\author{
Putri Febriana \\ Magister Psikologi, Program Pascasarjana, Universitas Ahmad Dahlan \\ putrifebriana03@gmail.com \\ Nina Zulida Situmorang \\ Magister Psikologi, Program Pascasarjana, Universitas Ahmad Dahlan \\ nina.situmorang@psy.uad.ac.id
}

\begin{abstract}
ABSTRAK
Perilaku agresi adalah suatu bentuk perilaku fisik maupun lisan yang bersifat negatif yang diawali dengan maksud dan tujuan untuk melukai dan menyakiti orang lain baik secara fisik maupun psikologis. Penelitian ini bertujuan untuk menggali lebih dalam tentang faktor-faktor penyebab terjadinya perilaku agresi pada remaja. Metode yang digunakan adalah metode kualitatif dengan pendekatan deskriptif. Subjek dalam penelitian ini berjumlah 6 orang remaja dengan usia sekitar 15-18 tahun. Teknik pengambilan data dengan menggunakan metode wawancara, observasi dan memberikan kuesioner dengan pertanyaan terbuka (open-ended questionnaire). Hasil penelitian mengungkapkan berbagai faktor-faktor yang menyebabkan munculnya perilaku agresi pada remaja, antara lain: (1) faktor teman sebaya dan lingkungan, (2) harga diri , dan (3) mencari kesenangan.
\end{abstract}

Kata Kunci: Faktor Penyebab, Perilaku Agresi, Remaja

\begin{abstract}
Aggression behavior is a form of negative physical and verbal behavior that begins with the intent and purpose to injure and hurt others both physically and psychologically. This study aims to dig deeper into the factors that cause aggression behavior in adolescents. The method used is a qualitative method with a descriptive approach. The subjects in this study amounted to 6 teenagers with ages around 15-18 years. Data collection techniques using interview, observation and giving questionnaires with open-ended questionnaire. The results revealed a variety of factors that led to the emergence of aggression in students, among others: (1) peer and environmental factors, (2) self-esteem, and (3) seeking pleasure.
\end{abstract}

Keywords : Adolescent, Aggression behavior, Factors causing

\section{PENDAHULUAN}

Masa remaja merupakan suatu tahapan perkembangan yang merupakan transisi dari masa kanakkanak menuju masa dewasa awal yang di mulai pada usia sekitar 10-12 tahun dan berakhir pada usia 1822 tahun. Pada masa ini terjadi perubahan-perubahan yang sangat menonjol yang dialami oleh remaja, baik secara psikologis maupun fisiologis. Perubahan tidak saja terjadi dari segi fisik, namun juga terjadi secara emosional, sosial dan personal sehingga pada saatnya menimbulkan perubahan yang drastis pada tingkah laku remaja (Santrock, 2007). Hurlock (1980) mengemukakan bahwa "Adolescenceis a time of 
Jurnal Psikologi Terapan dan Pendidikan

ISSN: $2715-2456$

Vol. 1, No. 1, Mei 2019, pp. 16-21

storm and stress". Remaja adalah masa yang penuh dengan badai dan tekanan jiwa, yaitu masa yang di mana terjadi perubahan besar secara fisik, intelektual dan emosional pada seseorang yang menyebabkan kesedihan dan kebimbangan (konflik) pada yang bersangkutan, serta menimbulkan konflik dengan lingkungannya.

Keadaan remaja yang masih dalam tahap perkembangan menjadikan berbagai aspek tersebut bersifat dinamis dan terus berubah-ubah. Remaja cenderung menggunakan emosi yang belum stabil dalam mengambil berbagai keputusan. Keadaan tersebut seringkali membawa remaja pada perilaku antisosial dan bahkan terjerumus pada perilaku kekerasan, yaitu perilaku agresi. Perilaku agresi merupakan fenomena yang umum terjadi di masyarakat. Agresi dikatakan sebagai bentuk perilaku yang dimaksudkan untuk menyakiti seseorang baik secara fisik maupun mental (Berkowitz, 1995). Sejalan dengan pendapat Berkowitz, Baron dan Byrne (2005) mendefinisikan bahwa agresi adalah perilaku yang secara sengaja ditujukan untuk menyakiti dan dapat menyebabkan luka pada orang lain, tanpa berpikir apakah niat menyakiti tersebut dapat mencapai sasaran atau tidak (apakah orang yang menjadi sasaran perilaku agresi merasakan sakit atau tidak).

Fenomena perilaku agresi remaja saat ini tidak pernah surut bahkan cenderung meningkat. Tindakan kekerasan atau perilaku agresi terjadi di seluruh dunia dan di seluruh lapisan masyarakat. Hasil penelitian Hidayat, Yusri, dan Ilyas (2013) mengungkapkan bahwa tindakan agresi siswa dilihat dari menyakiti orang secara fisik dengan presentase 35,32\%, sedangkan tindakan agresi yang dilakukan siswa dilihat dari menyakiti orang secara verbal sebanyak 41,30\% dan tindakan agresi dilihat dari merusak dan menghancurkan harta benda dengan presentase 30,42\%. Data lain berdasarkan hasil penelitian Marsh, McGee dan Williams (2014) bahwa perilaku agresi remaja usia 15-16 tahun dengan sampel sejumlah 1169 responden, sebanyak 70\% teridentifikasi sebagai korban dan pelaku agresi. Hasil penelitian Enopadria, Neherta dan Fernandes (2018) juga mengungkapkan bahwa sebanyak 5,7\% remaja awal, sebanyak $91,7 \%$ remaja tengah, dan sebanyak 2,6\% remaja akhir yang melakukan tindakan agresi.

Berdasarkan data KPAI (Komisi Perlindungan Anak Indonesia) terjadi sebanyak 206 kasus remaja usia 13-19 di tahun 2016, kemudian terjadi penurunan di tahun 2017 sebanyak 92 kasus, dan kembali meningkat di tahun 2018 sebanyak 265 kasus sebagai pelaku kekerasan fisik maupun verbal (penganiayaan, perkelahian, tawuran pelajar, bullying). Data terupdate diawal tahun Januari 2019 sudah ada 28 kasus remaja yang menjadi pelaku kekerasan fisik. Khususnya untuk di Provinsi Daerah Istimewa Yogyakarta, KPAI juga menyajikan data terakhir disepanjang tahun 2016 terdapat 6 korban dan 8 pelaku 
Jurnal Psikologi Terapan dan Pendidikan

ISSN: 2715-2456

Vol. 1, No. 1, Mei 2019, pp. 16-21

tawuran pelajar, 23 pelaku kekerasan fisik (pengeroyokan, penganiayaan, perkelahian, dan lain-lain), 4 pelaku kekerasan psikis (mengancam, mengintimidasi, dan lain-lain), 28 korban kekerasan fisik dan 3 korban kekerasan psikis (KPAI, 2019).

Yogyakarta dikenal sebagai kota pelajar, namun faktanya kasus kekerasan dikalangan remaja khususnya pelajar menengah atas masih banyak terjadi dan cenderung meningkat sehingga menjadi perhatian khusus masyarakat luas. Adanya kasus tersebut, tanpa disadari akan berdampak negatif pada citra kota Yogyakarta. Selain dikenal sebagai kota pelajar, Yogyakarta terkenal dengan kebudayaan Jawa yang khas. Keharmonisan sosial dalam masyarakat Jawa dipandang sebagai hal yang penting untuk dijaga. Untuk menjaganya, individu dianjurkan agar bersikap rukun dalam melakukan pergaulan sosial. Namun dalam realitasnya, perilaku tidak rukun yang mengganggu ataupun merusak harmoni sosial tetap saja terjadi. Bahkan, akhir-akhir ini berita perselisihan dan pertengkaran secara individu maupun kolektif seperti tawuran remaja menjadi bagian dari tayangan media massa (Faturochman, Minza, \& Nurjaman, 2017).

Beberapa faktor penyebab perilaku agresi, diantaranya ada pada kondisi internal dan eksternal. Gen, hormon, kimia darah, instink, stres, emosi, frustasi, dan konsep diri menjadi berbagai penyebab terjadinya perilaku agresi dalam kondisi internal. Sedangkan, keluarga, rekan sebaya, tetangga, dan sekolah menjadi faktor eksternal yang menyebabkan terjadinya perilaku agresi (Susantyo, 2011). Perilaku agresi signifikan disebabkan oleh adanya faktor internal, diantaranya frustasi, stress, kesepian dan keluarga (Estévez Lópe, Jiménez, \& Moreno, 2018). Hal yang serupa juga dikemukakan dari hasil penelitian Potirniche dan Enache (2014) bahwa faktor utama penyebab perilaku agresi adalah kondisi keluarga yang tidak baik dan tidak harmonis.

Faktor pemanasan global yang sedemikian cepat juga dapat meningkatkan kekerasan di seluruh dunia. Adanya peningkatan kemiskinan, kekurangan gizi, dan masalah dalam keluarga akan meningkatkan anak-anak yang berkembang menjadi remaja dan orang dewasa yang rentan terhadap perilaku agresi (Warburton \& Anderson, 2015). Perilaku agresi yang dilakukan seseorang muncul dari suatu dorongan (drive) yang ditimbulkan oleh faktor-faktor eksternal untuk menyakiti ataupun melukai orang lain. Teori dorongan atas agresi memunculkan perilaku untuk menyakiti orang lain. Teori dorongan atas agresi menjelaskan bahwa perilaku agresi terjadi dari dalam oleh dorongan untuk menyakiti orang lain. Dorongan-dorongan tersebut muncul dari berbagai kejadian eksternal (Baron \& Byrne, 2005).

Perilaku agresi akan memberikan dampak tersendiri terhadap diri sendiri sebagai pelaku, maupun dampak terhadap orang lain atau diluar dirinya sebagai korban dari perilaku agresi. Dampak bagi pelaku agresi yaitu akan dijauhi, dibenci dan ditakuti oleh teman-teman sebayanya. Sementara, dampak bagi 
Jurnal Psikologi Terapan dan Pendidikan

ISSN: $2715-2456$

Vol. 1, No. 1, Mei 2019, pp. 16-21

korban agresi yaitu dapat menimbulkan luka secara fisik maupun psikis dan perasaan rendah diri (Arifin \& Lukitaningsih, 2016). Melihat dampak-dampak dari perilaku agresi terhadap remaja tersebut, dalam jangka kedepan akan sangat berpengaruh terhadap perkembangan remaja itu sendiri, baik sebagai individu maupun lingkungan sosialnya.

Berdasarkan latar belakang yang telah dipaparkan di atas dan berbagai dampak yang akan terjadi dikemudian hari dengan adanya perilaku agresi, maka penelitian ini dilakukan untuk menjelaskan faktorfaktor apa saja penyebab terjadinya perilaku agresi pada remaja.

\section{METODE PENELITIAN}

Metode yang digunakan dalam penelitian ini adalah metode kualiatif deskriptif. Teknik pengambilan data dengan menggunakan metode wawancara, observasi dan memberikan kuesioner dengan pertanyaan terbuka (open-ended questionnaire). Subjek dalam penelitian ini berjumlah 6 orang remaja dengan usia sekitar 15-18 tahun, siswa disalah satu SMA Swasta di Kota Yogyakarta. Pemilihan sampel dalam penelitian ini dengan menggunakan teknik purposive sampling, yaitu teknik pengambilan data dengan segala pertimbangan tertentu agar sesuai dengan tujuan penelitian yang diharapkan sehingga memudahkan untuk mengkaji lebih dalam tentang objek sosial yang diteliti (Poerwandari, 2013). Pelaksanaan pada penelitian ini diawali dengan wawancara baik itu secara lisan maupun tulisan yang dilaksanakan pada rentang waktu mulai bulan Desember sampai dengan bulan Februari 2019.

\section{HASIL DAN PEMBAHASAN}

Keenam subjek dalam penelitian ini adalah siswa SMA yang pernah menyaksikan, mengalami, dan melakukan tindakan kekerasan fisik maupun verbal dalam kesehariannya. Berdasarkan hasil observasi, wawancara dan pertanyaan dalam kuesioner terbuka (open-ended questionnaire), diperoleh beberapa temuan tentang faktor-faktor penyebab terjadinya perilaku agresi di kalangan remaja khususnya siswa SMA, antara lain: a) Pengaruh teman sebaya dan lingkungan. Siswa melakukan perilaku agresi secara tidak sadar dipengaruhi oleh faktor lingkungan dan teman-teman di sekolah. Melalui "penularan" sosial, individu dapat berperilaku agresi. Lingkungan yang menjadi sangat menonjol peranannya dalam hal membentuk watak manusia (Nashori, 2008). Hasil penelitian Arifin dan Lukitaningsih (2016) menunjukkan bahwa secara umum perilaku agresi disebabkan oleh faktor lingkungan sekitar. Hal yang serupa juga dikemukakan dari hasil penelitian Trisnawati, Nauli dan Agrina (2014) yang menyatakan bahwa faktor-faktor yang dapat mempengaruhi perilaku agresi remaja yaitu adanya faktor status tempat tinggal, pola asuh orang tua, pengaruh teman sebaya, frustasi, dan pengaruh media elektronik. Fakta 
Jurnal Psikologi Terapan dan Pendidikan

ISSN: $2715-2456$

Vol. 1, No. 1, Mei 2019, pp. 16-21

membuktikan bahwa pelaku meniru perilaku agresi yang biasa ditunjukkan oleh lingkungan, baik teman maupun keluarga. b) Harga diri. Siswa melakukan perilaku agresi dengan niat sengaja untuk mencapai tujuan agar mereka lebih ingin diakui, ingin disegani, ingin terlihat mencolok dan memiliki kuasa serta ingin dihargai sebagai senior di lingkungan sekolah. Beberapa diantaranya motif utama seseorang berperilaku agresi adalah memiliki keinginan menyakiti orang lain untuk mengekspresikan perasaanperasaan negatif dan keinginan mencapai tujuan yang diinginkan melalui tindakan-tindakan agresi (Krahe, 2001). Seseorang dapat berperilaku agresi dikarenakan tidak dapat mengendalikan dirinya dengan sabar dan beranggapan bahwa harga diri itu seperti deindividuasi yang dapat mengarahkan individu pada keleluasan dalam melakukan agresi, sehingga agresi yang dilakukannya akan menjadi lebih intens (Dayaksini \& Hudaniah, 2009). c) Mencari kesenangan. Siswa menganggap bahwa tindakan agresi yang mereka lakukan sudah menjadi hal yang menyenangkan dan menjadi hal yang dianggap wajar untuk dilakukan sehari-hari. Perilaku individu pada dasarnya didorong oleh dua kekuatan dasar yang menjadi bagian yang tak terpisahkan dari sifat manusiawi. Pertama, insting kehidupan (eros) dan insting kematian (thanatos). Eros mendorong orang ke arah mencari kesenangan dan berusaha untuk memenuhi keinginan, sedangkan thanatos diarahkan pada destuksi diri. Jadi, agresi terhadap orang lain dianggap merupakan mekanisme untuk melepaskan energi destruktif sebagai cara melindungi stabilitas intrafisik pelakunya (Krahe, 2001).

\section{KESIMPULAN}

Dalam suatu tahapan perkembangan remaja, remaja cenderung menggunakan emosi yang belum stabil dalam mengambil berbagai keputusan. Keadaan tersebut membawa remaja pada perilaku kekerasan, yaitu perilaku agresi. Perilaku agresi adalah suatu bentuk perilaku fisik maupun lisan yang bersifat negatif yang diawali dengan maksud dan tujuan untuk melukai dan menyakiti orang lain. Banyak faktor yang dapat menyebabkan remaja dalam melakukan tindakan agresi. Berdasarkan kajian yang telah dilakukan, ditemukan beberapa faktor-faktor penyebab terjadinya perilaku agresi diantaranya adalah siswa melakukan perilaku agresi dipengaruhi oleh faktor teman sebaya dan lingkungannya, harga diri, serta mencari kesenangan.

\section{DAFTAR PUSTAKA}

Arifin, F. T., \& Lukitaningsih, R. (2016). Studi kasus perilaku agresif siswa SMTA Se-Kecamatan Badegan Kabupaten Ponorogo. BK, 6(2), 1-6

Baron, R. A. \& Byrne, D. (2005). Psikologi sosial (10th ed: et al Ratna Djuwita., Ed.). Jakarta: Erlangga. Berkowitz, L. (1995). Agresi 1 sebab dan akibatnya (H. W. Susiatni, Ed.). Jakarta: Pustaka Binaman 
Pressindo.

Dayaksini, T., \& Hudaniah. (2009). Psikologi sosial (5th ed.). Malang: UMM Press.

Enopadria, C., Neherta, M., \& Fernandes, F. (2018). The relationship of aggressive trauma and interpersonal relationships with aggressive adolescent behavior in Padang. 3(9), 384-387.

Estévez Lópe, E., Jiménez, T. I., \& Moreno, D. (2018). Aggressive behavior in adolescence as a predictor of personal, family, and school adjustment problems. Psicothema, 30(1), 66-73. https://doi.org/10.7334/psicothema2016.294.

Faturochman, Minza, W. M. \& Nurjaman, T. A. (2017). Memahami dan mengembangkan indigenous psychology (Cetakan 1). Yogyakarta: Pustaka Pelajar.

Hurlock, E. (1980). Psikologi perkembangan suatu pendekatan sepanjang rentang kehidupan (5th ed.; Istiwidayanti \& Soedjarwo, Eds.). Jakarta: Erlangga.

Hidayat, H., Yusri, \& Ilyas, A. (2013). Profil siswa agresif dan peranan guru BK. Konselor, 2(2), 7-10. https://doi.org/https://doi.org/10.24036/02013221644-0-00.

KPAI. (2019). Data kasus anak berdasarkan pemantauan media cetak. Retrieved from Bank Data Perlindungan Anak website: http://bankdata.kpai.go.id/tabulasi-data/data-kasus-dari-mediacetak/data-kasus-anak-berdasar-pemantauan-media-cetak-2016.

Krahe, B. (2001). Perilaku agresif (1st ed.; H. P. Soetjipto \& S. M. Soetjipto, Eds.). Yogyakarta: Pustaka Pelajar.

Marsh, L., McGee, R., \& Williams, S. (2014). School climate and aggression among new zealand high school students. New Zealand Journal of Psychology, 43(1), 28-37.

Nashori, F. (2008). Psikologi sosial islami. Bandung: Refika Aditama.

Poerwandari, E. K. (2013). Pendekatan kualitatif untuk penelitian perilaku manusia. Depok: Lembaga Pengembangan Sarana Pengukuran dan Pendidikan Psikologi (LPSP3) Fakultas Psikologi Indonesia.

Potirniche, N., \& Enache, R. G. (2014). Social perception of aggression by high school students. Procedia - Social and Behavioral Sciences, 127, 464-468. https://doi.org/10.1016/j.sbspro.2014.03.291

Santrock, J. W. (2007). Remaja jilid 2 (11th ed.; Benedictine Widyasinta, Ed.). Jakarta: Erlangga.

Susantyo, B. (2011). Memahami perilaku agresif: Sebuah tinjauan konseptual. Informasi, 16(03), 189202.

Trisnawati, J., Nauli, F. A., \& Agrina. (2014). Faktor-faktor yang mempengaruhi perilaku agresif remaja di SMK Negeri 2 Pekanbaru. Psikologi, 1(2), 1-9.

Warburton, W. A., \& Anderson, C. A. (2015). Aggression, social psychology of. International Encyclopedia of the Social \& Behavioral Sciences: Second Edition, 1, 373-380. https://doi.org/10.1016/B978-0-08-097086-8.24002-6 